\title{
Influence of Seed Priming on Biochemical Changes in Fresh and Aged Seeds of Sunflower (Helianthus annuus L.) Hybrid KBSH-53
}

\author{
B. Manjunatha*, B.C. Channakeshava, Y.G. Shadakshari, K. Bhanuprakash, \\ K.R. Sreeramulu and P. Balakrishna
}

Department of Seed Science and Technology, College of Agriculture, University of Agricultural Sciences, Bangalore-560065, Karnataka, India

*Corresponding author

\section{A B S T R A C T}

\begin{tabular}{|l|}
\hline K e y w or d s \\
$\begin{array}{l}\text { Sunflower } \\
\text { (Helianthus annuus } \\
\text { L.), Biochemical }\end{array}$ \\
\hline Article Info \\
\hline $\begin{array}{l}\text { Accepted: } \\
\text { 28 March } 2018 \\
\text { Available Online: } \\
\text { 10 April } 2018\end{array}$ \\
\hline
\end{tabular}

\section{Introduction}

Sunflower (Helianthus annuus L.) belongs to the family Astreaceae and it is one of the world's most important sources of vegetable oil. The native of sunflower is reported to be southern parts of USA and Mexico. Sunflower ranks third, next to groundnut and soybean in total production. In world it is cultivated in an area of 25.56 million hectares with an annual production of 40.64 million tonnes with productivity of $1590 \mathrm{~kg} \mathrm{ha}^{-1}$ during 2015 (Anon., 2016).

Sunflower was introduced to India during 1969 as a supplement to traditional oilseed
Priming on biochemical changes was tested on two seed lots $\mathrm{L}_{1}$ : Fresh seeds (> $91 \%$ Germination) and $\mathrm{L}_{2}$ : Aged seeds $(<70 \%$ Germination). The seeds were treated with priming chemicals 12 hours of soaking viz., $\mathrm{C}_{1}$ : Control, $\mathrm{C}_{2}$ : Hydropriming, $\mathrm{C}_{3}$ : $\mathrm{KH}_{2} \mathrm{PO}_{4}(1$ $\%), \mathrm{C}_{4}: \mathrm{GA}_{3}(400 \mathrm{ppm}), \mathrm{C}_{5}: \mathrm{NaCl}(1 \%), \mathrm{C}_{6}: \mathrm{KCl}(2 \%), \mathrm{C}_{7}: \mathrm{KNO}_{3}(2 \%), \mathrm{C}_{8}: \mathrm{CaCl}_{2} \cdot 2 \mathrm{H}_{2} \mathrm{O}$ $(2 \%), \mathrm{C}_{9}$ : PEG (-1Mpa), $\mathrm{C}_{10}$ : $\mathrm{K}_{2} \mathrm{HPO}_{4}(1 \%)$. Among the various seed priming treatments $\mathrm{KH}_{2} \mathrm{PO}_{4}(1 \%)$ is the suitable priming chemical to improve the marginal quality sunflower seed lots viz., higher total dehydrogenase activity (OD@ A480nm) (0.909), $\alpha$-Amylase activity (mg maltose liberated $\left.\min ^{-1} \mathrm{~g}^{-1}\right)(0.530)$, Peroxidase activity $(\Delta$ A436 nm min gram $\left.^{-1}\right)(0.732)$ and lower electrical conductivity $\left(1.722 \mathrm{dSm}^{-1}\right)$, as compared to control $\left(0.568,0.258\right.$ and $1.722 \mathrm{dSm}^{-1}$ respectively). Priming treatments are more effective in marginal seed lots compared to fresh seeds.

crops to bridge the gap of recurring edible oil shortage in the country. The commercial cultivation of sunflower was started in India during 1972-73 with an introduction of Russian varieties from USSR and Canada. Now, the crop is well adopted because of attributes such as short duration, photoperiod insensitivity, adoptability to wide range of soil and climatic conditions, drought tolerance, higher seed multiplication ratio $(1: 50)$ having high percentage of edible oil (45-50\%), which contains polyunsaturated fatty acid (PUFA). In recent years, India has emerged as second major sunflower producing country in Asia after China. In India, it is being grown in an area of 0.52 million hectares with annual 
production of 4.2 million tonnes having a productivity of $750 \mathrm{~kg} \mathrm{ha}^{-1}$ (Anon., 2014).

Priming in its traditional sense, soaking of seeds in water before sowing, has been the experience of farmers in India in an attempt to improve crop stand establishment but the practice was without the knowledge of the safe limit of soaking duration (Harris 1996). Moreover, Harris et al., (1999) promoted a low cost, low risk technology called 'on farm seed priming' that would be appropriate for all farmers, irrespective of their socio economic status. On-farm seed priming involves soaking the seed in water, surface drying and sowing the same day. The rationale is that sowing soaked seed decrease the time needed for germination and allow the seedling to escape deteriorating soil physical conditions. According to Khan (1992), osmotic conditioning in its modern sense, aims to reduce the time of seedling emergence, as well as synchronize and improve the germination percentage, by subjecting the seeds to a certain period of imbibition using osmotic solutions. The seeds normally begin water uptake on contact with this solution and stop the process as soon as they become balanced with the water potential of the solution.

Seed priming is basically a pre-sowing seed treatment. However, osmoprimed seeds may be dried back to their initial moisture content and stored for variable periods of time depending on the species. Primed and dried seeds normally have a more rapid and uniform germination when subsequently re-hydrated, especially under adverse environmental conditions (Bradford, 1986). The mechanism of seed drying after chemical priming is known as the hydration-dehydration process or dry back and is used to reduce the degree of moisture in seeds to levels compatible with storage and maintaining the beneficial effects of the treatment, without quality loss caused by rapid seed deterioration. The advantage of seed priming is reducing the germination time and improving emergence in field and laboratory conditions. However, few detailed studies have been reported on the performance of somatically treated seeds under field conditions. (Kumar et al., 1996) reported that priming of aged seeds of okra resulted in good germination and better crop establishment in the field trials. The benefits of seed priming was in terms of faster emergence, more and uniform stands, less need to re-sow, more vigorous plants, drought tolerance, earlier flowering, maturity and higher seed yield.

Beneficial effect of these seed priming treatments were reflected in greater cellular membrane integrity, counter action of lipid peroxidation and free radical chain reaction often found to be directly correlated with the maintenance of viability and reduced moisture uptake by hydrated dehydrated seeds (Dollypan and Basu, 1985), antipathogenic effects, repair of biochemical lesions by cellular enzymatic repair system and metabolic removal of toxic substances and counteraction of free radical and lipid peroxidation reactions (Rudrapal and Basu, 1982).

Invigoration of seeds is accompanied by certain biochemical changes in seed. Therefore, the present investigation was carried out to study the Influence of seed priming on biochemical changes in fresh and aged seeds of sunflower hybrid KBSH-53.

\section{Materials and Methods}

The laboratory experiment was conducted in 2016, at Department of Seed Science and Technology, University of Agricultural Sciences, Bengaluru. Treatments consists of sunflower hybrid KBSH-53 seed lots: $\mathrm{L}_{1}$ : Fresh seeds (>91\% Germination), $\mathrm{L}_{2}: 10$ months aged seeds $(<70 \%$ Germination $)$ and priming Treatments: $\mathrm{C}_{1}$ : Control, $\mathrm{C}_{2}$ : Hydro 
priming, $\mathrm{C}_{3}: \mathrm{KH}_{2} \mathrm{PO}_{4}(1 \%), \mathrm{C}_{4}: \mathrm{GA}_{3}(400$ ppm) $\mathrm{C}_{5}: \mathrm{NaCl}(1 \%), \mathrm{C}_{6}: \mathrm{KCl}(2 \%), \mathrm{C}_{7}$ : $\mathrm{KNO}_{3}(2 \%), \mathrm{C}_{8}: \mathrm{CaCl}_{2} \cdot 2 \mathrm{H}_{2} \mathrm{O}(2 \%), \mathrm{C}_{9}$ : PEG $(-1 \mathrm{Mpa})$ and $\mathrm{C}_{10}: \mathrm{K}_{2} \mathrm{HPO}_{4}(1 \%)$, seeds are soaked for 12 hours in solutions. The experiment was carried out in factorial completely randomized design in three replications and observations on various seed quality parameters were recorded.

\section{Electrical conductivity of seed leachate $\left(\mathbf{d S m}^{-1}\right)$}

Twenty five seeds of three replications were taken randomly from each treatment in a beaker. Then the seeds were soaked in $25 \mathrm{ml}$ of distilled water for 24 hours at $25 \pm 1{ }^{\circ} \mathrm{C}$. The steeped water from soaked seeds was collected and the electrical conductivity (EC) of seed the leachate was measured in digital conductivity meter (Model: Systronic conductivity meter 306 ).

After subtracting the EC of the distilled water from the value obtained from the seed leachate, the actual EC was measured and expressed in $\mathrm{dSm}^{-1}$.

\section{Total dehydrogenase activity (TDH)}

Ten sunflower seeds from each treatment were preconditioned by soaking in water for 24 hours. Then, seed coat was removed and soaked in $2 \mathrm{ml}$ of 0.5 per cent tetrazolium solution for four hours at $25 \pm 1{ }^{\circ} \mathrm{C}$ in dark and then washed thoroughly with distilled water. The red colour (Formazan) developed was eluted from the stained embryos by soaking in $5 \mathrm{ml}$ of 2 Methoxy ethanol in screw caped vials complete elution.

The extract was decanted and the colour intensity was measured in spectrophotometer (model SL 171) at $480 \mathrm{~nm}$ with suitable blank. The TDH was expressed in terms of absorbance value (Perl et al., 1983)
$\alpha$-Amylase activity (mg maltose liberated $\min ^{-1} \operatorname{gram}^{-1}$ )

\section{Reagents prepared}

\subsection{Phosphate buffer ( $\mathrm{pH} 7.0)$}

$1.0 \%$ Soluble starch solution: $1.0 \mathrm{~g}$ of soluble starch was dissolved in $100 \mathrm{ml}$ of warm $0.1 \mathrm{M}$ sodium acetate buffer ( $\mathrm{pH} 4.7$ )

Dinitrosalicylicacid (DNS) reagent: $1.0 \mathrm{~g}$ of 3, 5-dinitrosalicylicacid, $200 \mathrm{mg}$ of crystalline phenol and $50 \mathrm{mg}$ of sodium sulphite was dissolved in $100 \mathrm{ml}$ of 1 per cent $\mathrm{NaOH}$ solution by stirring. Reagent was stored in a stoppered bottle at $40{ }^{\circ} \mathrm{C}$.

$40 \%$ Rochelle salt solution (potassium sodium tartrate): $40 \mathrm{~g}$ of salt was dissolved in $100 \mathrm{ml}$ of water.

Standard maltose solution: $50 \mathrm{mg}$ of maltose was dissolved in water and the volume was made up to $50 \mathrm{ml}$ in a volumetric flask (1 $\mathrm{mg} / \mathrm{ml}$ ) and stored in refrigerator until the assay.

\section{Preparation of seed powder and enzyme extraction}

Seed powder was prepared from different ageing treatment seeds. Immediately after ageing, seeds were washed thoroughly and excess moisture was removed by blotting with tissue paper. Then $0.8 \mathrm{~g}$ seeds were frozen in liquid nitrogen and ground with the help of pestle and mortar. While grinding seed itself, $1.0 \mathrm{ml}$ of $0.1 \mathrm{M}$ phosphate buffer ( $\mathrm{pH} 7.0$ ) was added and the ground material was transferred to eppendorf tubes and kept at $4{ }^{\circ} \mathrm{C}$ overnight and then transferred to $-20{ }^{\circ} \mathrm{C}$.

The slurry was centrifuged at $10,000 \mathrm{rpm}$ for 15 minutes at $4{ }^{\circ} \mathrm{C}$ and the supernatant was used for $\alpha$-amylase assay. 


\section{Enzyme assay}

The $\alpha$-amylase assay was carried out according to the method of Bernfeld (1955) with slight modification. The enzyme assay of sample was carried out along with blank and control for each sample. For sample analysis $0.1 \mathrm{ml}$ of enzyme extract was taken in a cleaned test tube and $250 \mu \mathrm{l}$ of 1 per cent soluble starch was added and incubated for 15 min. To this $500 \mu 1$ of DNS reagent was added to stop the reaction and heated over water bath for $5 \mathrm{~min}$ and then cooled under running tap water after this, $250 \mu \mathrm{l}$ of $40 \%$ sodium potassium tartrate was added. Final volume of the reaction mixture was made to $5 \mathrm{ml}$ by adding $3.9 \mathrm{ml}$ of water. Absorbance was read at $560 \mathrm{~nm}$. A control was prepared for each sample similar to that of sample but the reaction was terminated at zero time. Similarly blank was prepared for each sample by omitting starch. Standard curve was prepared by using maltose ( 0 to $100 \mu \mathrm{g}$ ). One unit of enzymatic activity is defined as one $\mathrm{mg}$ of maltose liberated/hour under the standard assay conditions and specific activity as $\mathrm{mg}$ maltose liberated/min/gram seed.

\section{Peroxidase activity $\left(\Delta \mathrm{A} 436 \mathrm{~nm} \mathrm{~min}^{-1}\right.$ $\operatorname{gram}^{-1}$ )}

\section{Enzyme extraction}

One gram of sunflower seeds subjected to different ageing treatments were extracted in $1 \mathrm{ml}$ of $0.1 \mathrm{M}$ Phosphate buffer with $\mathrm{pH} 7.0$ by grinding with a pre cooled pestle and mortar.

The slurry was transferred to eppendorf tubes and kept at $4{ }^{\circ} \mathrm{C}$ for 4 hours for enzyme extraction and then tubes are transferred to 20 ${ }^{\circ} \mathrm{C}$. The homogenate was centrifuged at 10000 rpm at $4{ }^{\circ} \mathrm{C}$ for 15 minutes. The supernatant was used as enzyme source. The enzyme extract was stored in ice box till the assay is carried out.

\section{Preparation of reagents}

Phosphate buffer 0.1 M ( $\mathrm{pH} 7.0)$

Guaiacol solution $(20 \mathrm{mM}): 242 \mu \mathrm{l}$ guaiacol was added to distil water and the volume was made to $100 \mathrm{ml}$. It can be stored in frozen condition for many months.

Hydrogen peroxide solution (0.042\%) (12.3 $\mathrm{mM}$ ): $125 \mu \mathrm{l}$ of 30 per cent hydrogen peroxide was added to distilled water and volume was made to $100 \mathrm{ml}$. It should be prepared at the time of use. Absorbance of $12.3 \mathrm{mM} \mathrm{H}_{2} \mathrm{O}_{2}$ was adjusted to 0.4 by adding $20 \mathrm{ml}$ of water to it, before using the solution for assay.

\section{Estimation of peroxidase activity}

The enzyme assay was carried out as per the procedure of Sadasivam and Manickam (2008). The reaction mixture was prepared in cuvette by adding $2 \mathrm{ml}$ of $0.1 \mathrm{M}$ phosphate buffer of $\mathrm{pH}$ 7.0, Guaiacol-200 $\mu \mathrm{l}$ and 12.3 $\mathrm{mM} \mathrm{H} \mathrm{H}_{2} \mathrm{O}_{2}-200 \mu \mathrm{l}$. Brought the mixture to 25 ${ }^{\circ} \mathrm{C}$ and then placed the cuvette in the Spectrophotometer set at $436 \mathrm{~nm}$. Then, add $100 \mu$ of enzyme extract mix it properly with pipette tip, immediately start the stopwatch. Read the initial absorbance at $436 \mathrm{~nm}$ and note increase the absorbance for 3 minutes at an interval of 30 seconds by using enzyme kinetics. Water is used as blank during the assay period and enzyme activity was expressed in terms of change in absorbance per minute per gram of seed.

\section{Results and Discussion}

The data on electrical conductivity (EC) as influenced by the seed lots and priming treatments are presented in table 1. The electrical conductivity exhibited significant variations due to seed lots and priming treatments and their interactions. Between the seed lots, electrical conductivity was lower in 
$\mathrm{L}_{1}\left(0.291 \mathrm{dSm}^{-1}\right)$ and it was higher in $\mathrm{L}_{2}(2.861$ $\left.\mathrm{dSm}^{-1}\right)$. Among the priming treatments, lowest $\left(1.225 \mathrm{dSm}^{-1}\right)$ electrical conductivity was recorded in $\mathrm{C}_{3}$ followed by $\mathrm{C}_{4}$ and $\mathrm{C}_{10}(1.242$ and $1.442 \mathrm{dSm}^{-1}$ respectively). However, highest electrical conductivity was recorded in $\mathrm{C}_{1}\left(1.722 \mathrm{dSm}^{-1}\right)$. Electrical conductivity differed significantly due to $\mathrm{L} \times \mathrm{C}$. Among the interactions, lower electrical conductivity was recorded in $\mathrm{L}_{1} \mathrm{C}_{3}\left(0.117 \mathrm{dSm}^{-1}\right)$ followed by $\mathrm{L}_{1} \mathrm{C}_{4}$ and $\mathrm{L}_{1} \mathrm{C}_{9}\left(0.130 \mathrm{dSm}^{-1}\right)$. However, higher electrical conductivity was observed in $\mathrm{L}_{2} \mathrm{C}_{1}\left(3.237 \mathrm{dSm}^{-1}\right)$.

The EC value was significantly lower $(0.291$ $\mathrm{dSm}^{-1}$ ) in high vigour seeds compared to higher value $\left(2.861 \mathrm{dSm}^{-1}\right)$ recorded in low vigour seeds. High vigour seeds primed with $\mathrm{KH}_{2} \mathrm{PO}_{4}$ had registered lower EC $\left(1.225 \mathrm{dSm}^{-}\right.$ $\left.{ }^{1}\right)$ as against highest $\left(1.722 \mathrm{dSm}^{-1}\right)$ noticed in control. The EC value is used as an index of loss of cell membrane integrity and it is negatively correlated with the seed quality attributes. The distinct reduction in EC of seed leachate may be due to restoration of membrane integrity upon priming so that the leaching of electrolytes might be controlled in primed seeds (Sung and Chang, 1993). The similar results were also recorded by Sowmya (2011) in cucumber and Radha (2013) in maize.

The data on total dehydrogenase activity (TDH) as influenced by the seed lots and priming treatments are presented in table 1. The total dehydrogenase activity exhibited significant variations due to seed lots and priming treatments and their interactions. Between the seed lots, total dehydrogenase activity was higher in $\mathrm{L}_{1}(0.859)$ and it was lower in $\mathrm{L}_{2}$ (0.716). Among the priming treatments, highest total dehydrogenase activity was recorded in $\mathrm{C}_{3}(0.909)$ followed by $\mathrm{C}_{4}$ and $\mathrm{C}_{9}$ ( 0.904 and 0.896 respectively). However, lowest total dehydrogenase activity was recorded in $\mathrm{C}_{1}$ (0.568). Total dehydrogenase activity differed significantly due to $\mathrm{L} \times \mathrm{C}$. Among the interactions, higher total dehydrogenase activity was recorded in $\mathrm{L}_{1} \mathrm{C}_{3}$ (0.976) and $\mathrm{L}_{1} \mathrm{C}_{4}$ followed by $\mathrm{L}_{1} \mathrm{C}_{9}$ and $\mathrm{L}_{1} \mathrm{C}_{10} \quad(0.950$ and 0.943 respectively). However, lower (0.427) total dehydrogenase activity was observed in $\mathrm{L}_{2} \mathrm{C}_{1}$. The TDH was higher $(0.859)$ in high vigour seeds but it was extremely lower (0.716) in low vigour seeds.

Among the priming treatments, higher total dehydrogenase activity (0.909) was recorded in $\mathrm{KH}_{2} \mathrm{PO}_{4}$ (primed seeds $\left(\mathrm{C}_{3}\right)$ and it was lower $(0.568)$ in control $\left(\mathrm{T}_{1}\right)$. Increased TDH activity might be an index of increased cellular biosynthetic activities like DNA and RNA synthesis that in turn indicate the higher protein and energy production necessary for germination and seedling emergence (Osborne et al., 1980). Priming increased enzyme activity as well as counteracted the effects of lipid peroxidation. Saha et al., (1990) showed that priming caused increased $\alpha$-Amylase and dehydrogenase activity in aged soybean seeds compared to unprimed seeds while decreased lipid peroxidation. The results are in line with Sowmya (2011) in cucumber and Radha (2013) in maize.

The data on $\alpha$-Amylase activity as influenced by the seed lots and priming treatments are presented in table 2 . The $\alpha$-Amylase activity exhibited significant variations due to seed lots and priming treatments and their interactions. Between the seed lots, $\alpha$-Amylase activity was higher in $\mathrm{L}_{1}(0.507 \mathrm{mg}$ maltose liberated $\min ^{-1} \mathrm{~g}^{-1}$ ) and it was lower in $\mathrm{L}_{2}$ (0.263). Among the priming treatments, highest $\alpha$-Amylase activity was recorded in $\mathrm{C}_{3}$ $\left(0.530 \mathrm{mg}\right.$ maltose liberated $\left.\min ^{-1} \mathrm{~g}^{-1}\right)$ followed by $\mathrm{C}_{4}$ and $\mathrm{C}_{9}(0.515$ and $0.490 \mathrm{mg}$ maltose liberated $\min ^{-1} \mathrm{~g}^{-1}$ respectively). However, lowest $\alpha$-Amylase activity was recorded in $\mathrm{C}_{1}(0.258 \mathrm{mg}$ maltose liberated $\left.\min ^{-1} \mathrm{~g}^{-1}\right) . \quad \alpha$-Amylase activity differed significantly due to $\mathrm{L} \times \mathrm{C}$. 
Table.1 Influence of seed lots and priming treatments on electrical conductivity $\left(\mathrm{dSm}^{-1}\right)$ and dehydrogenase activity (A480) of sunflower hybrid KBSH-53

\begin{tabular}{|c|c|c|c|c|c|c|}
\hline \multirow[t]{2}{*}{ Treatments } & \multicolumn{3}{|c|}{ Electrical conductivity $\left(\mathrm{dSm}^{-1}\right)$} & \multicolumn{3}{|c|}{ Dehydrogenase activity (A480) } \\
\hline & $\mathbf{L}_{1}$ & $\mathbf{L}_{2}$ & Mean & $\mathbf{L}_{1}$ & $\mathbf{L}_{2}$ & Mean \\
\hline $\mathrm{C}_{1}$ & 0.207 & 3.237 & 1.722 & $\mathbf{L}_{1}$ & $\mathbf{L}_{2}$ & 0.568 \\
\hline $\mathrm{C}_{2}$ & 0.190 & 3.147 & 1.668 & 0.710 & 0.427 & 0.675 \\
\hline $\mathrm{C}_{3}$ & 0.117 & 2.333 & 1.225 & 0.740 & 0.610 & 0.909 \\
\hline $\mathrm{C}_{4}$ & 0.130 & 2.353 & 1.242 & 0.976 & 0.842 & 0.904 \\
\hline $\mathrm{C}_{5}$ & 0.167 & 3.153 & 1.660 & 0.976 & 0.833 & 0.715 \\
\hline $\mathrm{C}_{6}$ & 0.163 & 3.040 & 1.602 & 0.780 & 0.650 & 0.730 \\
\hline $\mathrm{C}_{7}$ & 0.157 & 2.857 & 1.507 & 0.790 & 0.670 & 0.792 \\
\hline $\mathrm{C}_{8}$ & 0.140 & 2.743 & 1.442 & 0.850 & 0.733 & 0.820 \\
\hline$\overline{\mathrm{C}_{9}}$ & 0.130 & 2.823 & 1.477 & 0.877 & 0.763 & 0.896 \\
\hline $\mathrm{C}_{10}$ & 1.507 & 2.920 & 2.213 & 0.950 & 0.843 & 0.867 \\
\hline \multirow[t]{2}{*}{ Mean } & 0.291 & 2.861 & \multirow[t]{2}{*}{$\mathrm{CV}(\%)$} & 0.943 & 0.791 & \multirow[t]{2}{*}{$\mathrm{CV}(\%)$} \\
\hline & S.Em \pm & $\mathrm{CD}(\mathrm{P}=\mathbf{0 . 0 1})$ & & 0.859 & 0.716 & \\
\hline$\overline{\mathbf{L}}$ & 0.008 & 0.024 & \multirow{3}{*}{3.58} & S.Em \pm & $\mathrm{CD}(\mathrm{P}=0.01)$ & \multirow{3}{*}{3.02} \\
\hline $\mathrm{C}$ & 0.019 & 0.054 & & 0.003 & 0.011 & \\
\hline $\mathbf{L C}$ & 0.026 & 0.077 & & 0.008 & 0.024 & \\
\hline \multicolumn{2}{|c|}{$\begin{array}{l}\text { Lots: } \\
\left.\mathrm{L}_{1}: \text { Fresh seeds ( }>91 \% \text { Germination }\right) \\
\mathrm{L}_{2}: 10 \text { months aged seeds }(<70 \% \text { Germination })\end{array}$} & $\begin{array}{l}\text { Priming Tr } \\
\mathrm{C}_{1}: \text { Control } \\
\mathrm{C}_{2}: \text { Hydropr } \\
\mathrm{C}_{3}: \mathrm{KH}_{2} \mathrm{PO}_{4} \\
\mathrm{C}_{4}: \mathrm{GA}_{3}(40\end{array}$ & \multicolumn{2}{|r|}{$\begin{array}{l}\mathrm{C}_{5}: \mathrm{NaCl}(1 \%) \\
\mathrm{C}_{6}: \mathrm{KCl}(2 \%) \\
\mathrm{C}_{7}: \mathrm{KNO}_{3}(2 \%) \\
\mathrm{C}_{8}: \mathrm{CaCl}_{2} \cdot 2 \mathrm{H}_{2} \mathrm{O}(2 \%)\end{array}$} & \multicolumn{2}{|c|}{$\begin{array}{l}\mathrm{C}_{9}: \text { PEG (-1 Mpa) } \\
\mathrm{C}_{10}: \mathrm{K}_{2} \mathrm{HPO}_{4}(1 \%)\end{array}$} \\
\hline
\end{tabular}


Table.2 Influence of seed lots and priming treatments on $\alpha$ - amylase (mg maltose liberated $\min ^{-1}$ gram $^{-1}$ ) and peroxidase $\left(\triangle \mathrm{A} 436 \mathrm{~nm} \mathrm{~min}^{-1} \mathrm{gram}^{-1}\right)$ of sunflower hybrid KBSH-53

\begin{tabular}{|c|c|c|c|c|c|c|}
\hline \multirow[t]{2}{*}{ Treatments } & \multicolumn{3}{|c|}{$\alpha$-Amylase (mg maltose liberated min $^{-1}$ gram $^{-1}$ ) } & \multicolumn{3}{|c|}{ Peroxidase $\left(\triangle \mathrm{A} 436 \mathrm{~nm} \mathrm{~min}^{-1} \mathrm{gram}^{-1}\right)$} \\
\hline & $\mathbf{L}_{1}$ & $\mathbf{L}_{2}$ & Mean & $\mathbf{L}_{1}$ & $\mathbf{L}_{2}$ & Mean \\
\hline $\mathrm{C}_{1}$ & 0.323 & 0.193 & 0.258 & 0.687 & 0.307 & 0.497 \\
\hline $\mathrm{C}_{2}$ & 0.337 & 0.200 & 0.268 & 0.713 & 0.333 & 0.523 \\
\hline $\mathbf{C}_{3}$ & 0.723 & 0.337 & 0.530 & 0.927 & 0.537 & 0.732 \\
\hline $\mathrm{C}_{4}$ & 0.710 & 0.320 & 0.515 & 0.910 & 0.540 & 0.725 \\
\hline $\mathrm{C}_{5}$ & 0.340 & 0.247 & 0.293 & 0.730 & 0.530 & 0.630 \\
\hline $\mathrm{C}_{6}$ & 0.350 & 0.243 & 0.297 & 0.757 & 0.450 & 0.603 \\
\hline $\mathrm{C}_{7}$ & 0.417 & 0.270 & 0.343 & 0.790 & 0.490 & 0.640 \\
\hline $\mathrm{C}_{8}$ & 0.537 & 0.273 & 0.405 & 0.827 & 0.521 & 0.674 \\
\hline $\mathrm{C}_{9}$ & 0.693 & 0.287 & 0.490 & 0.870 & 0.591 & 0.731 \\
\hline $\mathbf{C}_{10}$ & 0.640 & 0.257 & 0.448 & 0.853 & 0.573 & 0.713 \\
\hline \multirow[t]{2}{*}{ Mean } & 0.507 & 0.263 & \multirow[t]{2}{*}{ CV (\%) } & 0.806 & 0.487 & $\mathrm{CV}(\%)$ \\
\hline & S.Em \pm & $\mathrm{CD}(\mathrm{P}=\mathbf{0 . 0 1})$ & & S.Em \pm & $\mathrm{CD}(\mathrm{P}=\mathbf{0 . 0 1})$ & \multirow{4}{*}{4.56} \\
\hline$\overline{\mathbf{L}}$ & 0.008 & 0.024 & \multirow{3}{*}{4.02} & 0.004 & 0.012 & \\
\hline $\mathrm{C}$ & 0.019 & 0.055 & & 0.010 & 0.028 & \\
\hline $\mathbf{L C}$ & 0.027 & 0.078 & & 0.014 & 0.040 & \\
\hline \multicolumn{2}{|c|}{$\begin{array}{l}\text { Lots: } \\
\left.\mathrm{L}_{1}: \text { Fresh seeds ( }>91 \% \text { Germination }\right) \\
\mathrm{L}_{2}: 10 \text { months aged seeds }(<70 \% \text { Germination })\end{array}$} & $\begin{array}{l}\text { Priming Tr } \\
\mathrm{C}_{1}: \text { Control } \\
\mathrm{C}_{2}: \text { Hydrop } \\
\mathrm{C}_{3}: \mathrm{KH}_{2} \mathrm{PO} \\
\mathrm{C}_{4}: \mathrm{GA}_{3}(4 \mathrm{C}\end{array}$ & \multicolumn{2}{|r|}{$\begin{array}{l}\mathrm{C}_{5}: \mathrm{NaCl}(1 \%) \\
\mathrm{C}_{6}: \mathrm{KCl}(2 \%) \\
\mathrm{C}_{7}: \mathrm{KNO}_{3}(2 \%) \\
\mathrm{C}_{8}: \mathrm{CaCl}_{2} \cdot 2 \mathrm{H}_{2} \mathrm{O}(2 \%)\end{array}$} & \multicolumn{2}{|c|}{$\begin{array}{l}\mathrm{C}_{9}: \text { PEG }(-1 \mathrm{Mpa}) \\
\mathrm{C}_{10}: \mathrm{K}_{2} \mathrm{HPO}_{4}(1 \%)\end{array}$} \\
\hline
\end{tabular}


Among the interactions, higher $\alpha$-Amylase activity was recorded in $\mathrm{L}_{1} \mathrm{C}_{3}$ followed by $\mathrm{L}_{1} \mathrm{C}_{4}\left(0.723 \mathrm{mg}\right.$ maltose liberated $\left.\min ^{-1} \mathrm{~g}^{-1}\right)$ and $\mathrm{L}_{1} \mathrm{C}_{9}(0.710$, and $0.693 \mathrm{mg}$ maltose liberated $\min ^{-1} \mathrm{~g}^{-1}$ respectively). However, lower $\alpha$-Amylase activity was observed in $\mathrm{L}_{2} \mathrm{C}_{1}\left(0.193 \mathrm{mg}\right.$ maltose $\left.\mathrm{min}^{-1} \mathrm{~g}^{-1}\right)$. Priming increased enzyme activity as well as counteracted the effects of lipid peroxidation. Saha et al., (1990) showed that priming caused increased $\alpha$-Amylase and dehydrogenase activity in aged soybean seeds compared to unprimed seeds while decreased lipid peroxidation. The results are in line with Sowmya, (2011) in cucumber and Radha (2013) in maize.

The data on peroxidase activity as influenced by the seed lots and priming treatments are presented in table 2 . The peroxidase activity exhibited significant variations due to seed lots and priming treatments and their interactions. Between the seed lots, peroxidase activity was higher in $\mathrm{L}_{1}(0.806)$ and it was lower in $\mathrm{L}_{2}$ (0.487). Among the priming treatments, highest peroxidase activity was recorded in $\mathrm{C}_{3}$ (0.732) followed by $\mathrm{C}_{4}$ and $\mathrm{C}_{9}(0.725$ and 0.731 respectively). However, lowest peroxidase activity was recorded in $\mathrm{C}_{1}$ (0.497). Peroxidase activity differed significantly due to $\mathrm{L} \times \mathrm{C}$. Among the interactions, higher peroxidase activity was recorded in $\mathrm{L}_{1} \mathrm{C}_{3}(0.927)$ followed by $\mathrm{L}_{1} \mathrm{C}_{4}$ and $\mathrm{L}_{1} \mathrm{C}_{9}(0.910$ and 0.870 respectively). However, lower peroxidase activity was observed in $\mathrm{L}_{2} \mathrm{C}_{1}$ (0.307). Increased activity of free radicle scavenging enzymes such as superoxide dismutase, catalase, and peroxidase and glyoxysome enzymes such as isocitrate lyase and malate synthase upon priming. The results are in line with Sowmya (2011) in cucumber and Radha (2013) in maize.

It is evident from the present study seeds primed with $\mathrm{KH}_{2} \mathrm{PO}_{4}(1 \%)$ shows lower electrical conductivity of seed leachates (EC), higher dehydrogenase activity, $\alpha$-Amylase activity and Peroxidase activity where, as seeds without priming shows higher EC, lower dehydrogenase activity, $\alpha$-Amylase activity and Peroxidase activity. The correlation of biochemical parameters correlated with the vigour and viability of sunflower seeds showed that the electrical conductivity of seed leachates (EC) increases, vigour and viability of sunflower seeds decreases and high dehydrogenase activity was found to favour for invigouration of seeds.

\section{References}

Anonymous, 2014, Production Year Book, Food and Agricultural Organization, Rome.

Anonymous, 2016, Database on oilseed area, production and productivity, DOR, Directorate of Oilseeds Research, Rajendranagar, Hyderabad.

Bernfeld, P., 1955, Amylases- V and E In: Methods in Enzymology, Academic Press, New York, pp.149-155.

Bradford, K. J., 1986, Manipulation of seeds water relations via osmotic priming to improve germination under stress conditions. Hort. Sci., 59(2): 672-676.

Dollypan and Basu, R. N., 1985, Mid-storage and pre-sowing seed treatments for lettuce and carrot. Scientia Hort., 33(6): 1026-1027.

Harris, D., 1996, Effects of manure, genotype, seed priming, depth and date of sowing on the emergence and early growth of Sorghum bicolor (L.) Moench in semiarid Botswana. Soil Tillage Res., 40:7388.

Harris, D., Joshi, A., Khan, P. A., Gothkar, P. and Sodhi, P. S., 1999, On-farm seed priming in Semi-arid agriculture: development and evaluation in maize, rice and chickpea in India using 
participatory methods, Exp. Agric, 35: 15-29.

Khan, A. A., 1992, Pre-plant physiological conditioning. Hort. Rew., 13: 131-181.

Kumar, S., Singh, P., Katiyar, R. P., Vaish C. P. and Khan, A. A., 1996, Beneficial effect of some plant growth regulators on aged seeds of okra (Abelmoschus esculentus (L.) Moench.) under field conditions. Not Sci. Biol, 21(2): 34-37.

Osborne, D. J., Sharon, and Benishai, R., 1980, Studies on DNA integrity and DNA repairing germinating embryos of rye (Secale cereal). Israel. J. Bot, 29:259-272.

Perl, M., Luria, I.G and Gelmand, H., 1983, Biochemical changes in sorghum seeds affected by accelerated ageing. $J$. Expt. Bot., 29:497-509.

Radha, B. N. 2013, Studies on influence of provenances, seed priming and seed storage in hybrid maize (Zea mays L.). Ph.D. Thesis. University of Agricultural sciences, Bangalore.

Rudrapal, A. B. and Basu, R. N., 1982, Use of chlorine and bromine in controlling mustard seed deterioration. Seed Res., 9: 188-191.

Sadasivam, S. and Manickam, 2008, Biochemical methods, Chapter IV: Enzymes, Peroxidase. New age International publishers, New Delhi, Pp: 100-101.

Saha, R., Mandal, A. K. and Basu, R. N., 1990, Physiology of seed invigouration treatment in soybean (Glycine max L.). Seed Science and Technology, 18: 269276.

Sowmya, K. J., 2011, Studies on physiological, Biochemical and molecular aspects of seed invigouration in cucumber (Cucumis sativus L.). Ph.D. Thesis University of Agricultural sciences, Bangalore.

Sung, F. J. M. and Chang, Y. H., 1993, Biochemical activities associated with priming of sweet corn seeds to improve vigour. Seed Science and Technology, 21: $97-105$.

\section{How to cite this article:}

Manjunatha, B., B.C. Channakeshava, Y.G. Shadakshari, K. Bhanuprakash, K.R. Sreeramulu and Balakrishna, P. 2018. Influence of Seed Priming on Biochemical Changes in Fresh and Aged Seeds of Sunflower (Helianthus annuus L.) Hybrid KBSH-53. Int.J.Curr.Microbiol.App.Sci. 7(04): 3543-3551. doi: https://doi.org/10.20546/ijcmas.2018.704.399 